\title{
BPI Gene
}

National Cancer Institute

\section{Source}

National Cancer Institute. BPI Gene. NCI Thesaurus. Code C106600.

This gene is involved in lipopolysaccharide binding. 